\title{
OVERVIEW HISTORY OF NEDERLANDSCH-INDIE MARITIME LAW IN TWENTIETH CENTURY BATAVIA
}

\author{
Rendy Kurniawan \\ Jurusan Sejarah Peradaban Islam \\ Fakultas Adab dan Humaniora \\ Universitas Islam Negeri Sunan Gunung Djati Bandung \\ Email: kurniawanrendy199898@gmail.com
}

\begin{abstract}
Abstrak
This study is aimed at sketching out one of the outstanding influence from Dutch to Nusantara. It was the forming of the maritime law which known as scheepvaart aangelegenheden in Batavia that becomes the focus of this study. By doing this, Dutch government had their own regulation to control each port centralizing in Batavia. With this regulation, Dutch government could deal with the busy ports in Nederlandsch Indie much easier than before. This study is applying qualitative method which involves documents and law manuscript discussion. The result shows that although a number of articles in the law had strongly influenced by Nusantara's local kingdoms, there were still many various important things.
\end{abstract}

Keywords : dutch government, maritime law, local kingdom, Batavia 


\section{Introduction}

In history of Nederlandsch Indie, harbors are somehow crucial. They played big roles to maritime business and economy. Goods trade, distribution and export might be a number of examples of harbors function in the history of Nederlandsch Indie. With this fact, we cannot deny that harbors is somewhat busy and they were indeed involved deeply in the history of Indonesia's maritime discourse. Therefore, harbors could not left without any regulation.

Considering the maritime regulation, Nusantara's local kingdom had somehow much more advance in regulating their harbor. They did not recklessly left their harbor without any regulation, something that could really dangerous for economy and trade. For example, Aceh in its history had originated Adat Sagala Radja which concerning mostly on how the ship which anchored to Aceh's harbor should pay tax and how far the task of port operators were. ${ }^{1}$

Another example are coming from Melayu. They also generated their own maritime law. It was well known as Undang-Undang Laut Melaka. By doing this, local authority could control a number of aspects regarding to the harbor organization, goods export and import and ship taxes. In turn, with the involvement of this regulation to the Melaka's maritime sector, the local kingdom was somehow achieving excellent incomes. ${ }^{2}$

Concerning this idea, Dutch did not end up being careless to the harbors in Nederlandsch Indie. In order to keep their hand on controlling the busy harbors, like what the local kingdoms did, they generate a number of examples which concerning mostly on organizing the harbors, especially Batavia's central harbor. With this regulation, most of the ship which took sail on Nederlandsch Indies harbors should pay an extreme caution.

Together with discussion above, this particular study specifically focuses on history of Dutch maritime regulation in Nederlandsch Indie in Dutch Government, centralizing in Batavia within twentieth century. This would help us to understand how far the influence of local kingdoms through the Dutch maritime's law, vice versa. In fact, we cannot help to mention that

\footnotetext{
${ }^{1}$ Denys Lombard, Kerajaan Aceh (Jakarta: Gramedia, 2014).

${ }^{2}$ Ahmad Halimi Jaelami, "Undang-Undang Laut Melayu: Undang-Undang Perahu Dan Undang-Undang Berlayar,” Pusat Pengkajian Umum Dan Naskah Adat Aceh, 1985.
} 
Indonesia contemporary maritime law is somewhat influenced by Dutch regulation in the past. Therefore, it is interesting to discuss this issue.

\section{Result and Discussion \\ Overview History of Harbor of Batavia}

In general, Batavia as the center of port cities within Nederlandsch Indie had well known as 'Queen of the Orient' back in seventeenth century. It was because the multicultural places poured in one specific place, something that hardly found in other different place at that time. ${ }^{3}$ A hundred years after, because of sophisticated reasons, this city had been popular no more. With this fact, in this part, several factors of Batavia maritime history under the Dutch control would be elaborated.

To begin with, earliest harbors which known as Sunda Kalapa was established by VOC together with the construction of the city. Mentioned as one of the most important ports for business, Batavia is somewhat fortune for Nederlandsch Indie. As the VOC capital, the port in Batavia was extremely important for business and maritime discourse. Until the end of 17th, this port played a big role for VOC. Their ships were stop in Batavia before continuing their journey to many places from China to India. ${ }^{4}$

In eighteenth century, as I have mentioned before, Batavia in this period was well known as 'Queen of Orient' because of its beauty. Its atmosphere was somewhat splendid. Ciliwung was elegantly lined by surrounding trees. Public houses were constructed neatly with brick. The streets were providing brich-paved for pedestrian convenience. ${ }^{5}$ This reflects the well-organized city in Eighteenth century period.

Beside, in the same time, export-import lane of Batavia was exponentially increasing. Along the eighteenth century, the port of Batavia supplying the income of colonial economy with an important quantity of goods. Rubber, cocoa beans, spices, wood, and gold were a number of examples of how far the Nederlandsch Indie had encourage colonial state

\footnotetext{
${ }^{3}$ Marsely L Kehoe, "Dutch Batavia: Exposing the Hierarchy of the Dutch Colonial City," Journal of Historians of Netherlandish Art 7 (1), 2015.

4 Annisa Gultom, "Kalapa-Jacatra-Batavia-Jakarta: An Old City That Never Gets Old," Journal of Archeology and Fine Arts in Southeast Asia 2, 2018.

${ }^{5}$ Leonard Blusse, Visible Cities: Canton, Nagasaki and Batavia and the Coming of Americans (London: Harvard University Press, 2008).
} 
income. In Average, Nederlandsch Indies income was accounted for 13.5\% of total Dutch Government income per year. ${ }^{6}$

However, this achievement was not without challenge. After the breakdown of VOC in 1799, Dutch Kingdom took over the Nederlandsch Indie administration of maritime affair. With this transition, Dutch Government tend to open the market for private enterprise to be involved.

Government and particular private enterprises were then forming Koninlijk Paketvaart Maatschapij (KPM) which deal with ship and trading in Batavia. In turn, Batavia port was crowded by many ships from different companies. $^{7}$

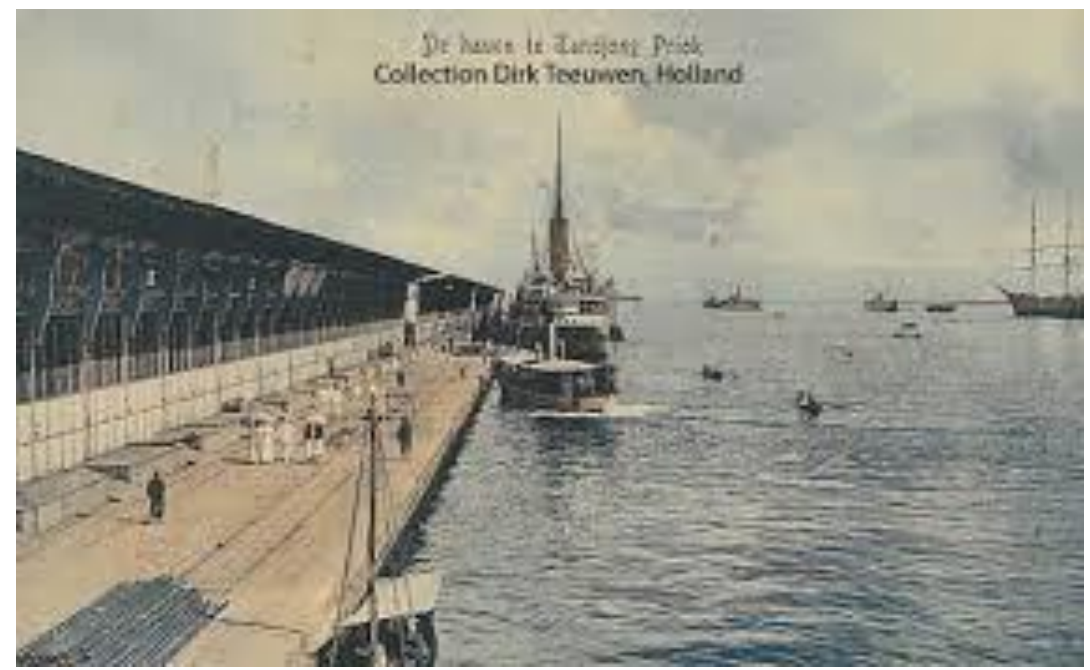

Potrait of Batavia Port in the end of Nineteenth centuries

Source : Dirk Teeuwen Postcard Collection, 1895

Entering the twentieth century, together with the opening of Suez Canal in 1869, Sunda Kalapa port activity had sharply developed. With this situation, it was uneffective to try maintaining Sunda Kalapa to become the main port of government harbor. Therefore, with many controversy from many other side, Dutch Government had constructed Tandjung Priok port five mils from the previous harbor. ${ }^{8}$ This might be the reason why Dutch

\footnotetext{
${ }^{6}$ H. Blink, General View of the Netherlands (Batavia, 1915).

${ }^{7}$ Lillyana Mulya, "KEBIJAKAN MARITIM DI HINDIA BELANDA: Langkah Komersil Pemerintah Kolonial," MOZAIK: Jurnal Ilmu-Ilmu Sosial Dan Humaniora 7 (1), 2018.

${ }^{8}$ Baihaqi, Ahmad Fauzan, and Zakiya Darojat, "The Transition of the Central Port of Colonial Era : From Old Batavia to TanjungPriok Port." Journal of Islam and Humanities," 2018.
} 
Government was re-organizing the regulation concerning ships management in Batavia's port.

\section{A. Dutch Maritime Law in Twentieth Century : Study on Scheepvaart Aangelegenheden}

In order to look deep into history of maritime law in eary twentieth century, we cannot deny one of the most important maritime regulation in the history of Nederlandch Indie, it was Scheepvaart aangelegenheden. This law in general were conducted in entire Java and Madura. But specifically, this ordonantie was effectively work in Batavia. It seems that this law was generated because the fact that Dutch Government had new port known as Tandjung Priok. Within the discussion below, three pillars of maritime law according to Lapian ${ }^{9}$ would be elaborated, they were harbor manager, ship license, and tax withdrawal.

\section{B. Harbor Manage}

Port operators are one of the most important pillar in maritime system. It's importance lies in their contribution through the management of harbors including in-exit lane of ship, tax enforcement, trading operator, and ports maintenance itself. Dutch maritime law, in particular, have a number of features.

To begin with, the harbor under the Dutch control in twentieth century led by harbormaster called Syahbandar. This harbormaster was aimed to be in charge of the harbor itself and organized the management of ship and tax as well. As and addition, this law was also determinating how was the procedure of Syahbandar recruitment. In fact, it was not only Batavia in twentieth century mentioning Syahbandar as their harbormaster's title. Aceh and Malaka had also mentioned Syahbandar within their own particular law. ${ }^{10}$

Apart from the other local kingdom, when determining the harbormaster, Dutch choosed Syahbandar by fair appointment examined by local district head. In Batavia for example, the Staatsblad of Gouvernor General of Nederlandsch Indie resolved the appointment of harbormaster in

\footnotetext{
${ }^{9}$ Adrian B. Lapian, Pelayaran Dan Perniagaan Nusantara Abad Ke 16 Dan 17. (Jakarta: Komunitas Bambu, 2008).

${ }^{10}$ KITLV, Adat Aceh (Jakarta: Departemen Pendidikan dan Kebudayaan, 1985).
} 
each port was handed over to the authorities where Batavia port located. ${ }^{11}$ This was very acceptable, remembering that in the other Ordonanntie from the Scheepvaart Aangelegenheid in 1924 stated that Syahbandar should fulfill the general position requirements and proven by district head's recommendation. Therefore, rather than choosing their harbormaster carelessly, the district head in Batavia promoted the Syahbandar after the requirements had fulfilled. With this fact, the Dutch Government tend to try their best in order to organizing the harbor.

The second point was on the harbor managemet which helped the Syahbandar in a number of ports under Dutch Government. Indeed, the harbor officers to help Syahabandar is somewhat crucial. Regarding to the harbor official, they referred the officers in particular name with the task they are charging in. In general, they helped the Syahbandar to collect the tax, manage the ship, and sometimes take care of medical problems. ${ }^{12}$

For the multicultural societies under Dutch control, which centered Batavia, it has quite legal name of harbor officer. In 1918, the Scheepvaart Aangelegenheid mention implicitly that Syahbandar in Batavia was helped by several officers. For instance ; Scheepmeter and Keurkomissieren who helps harbormaster doing his job. Scheepmater played an important role to measure how big the ship was and determine how much they should pay the tax. Keurkomissieren had the task to sign the ship approval.

However, there are another case when the law also mentioned various instrument of harbor. Look at the article of disease articles. There were also mentioning the presence of doctor, police, tax withdrawer, and even to the priest of Christian within particular ship. Eventhough the name are different, those officers were normally work to help Syahbandar. ${ }^{13}$

\section{B. Ship License}

Among the system of enter-exit lane of the shipping and sailing in harbor, ship marks and license release were playing a big role to manage the traffic between sea and river routes. It decides which ships could sailed and banned in the harbor. With its importance, Batavia had decided their own

\footnotetext{
11 Departement van Binnenlandsch-Bestuur, Scheepvaart Aangelegenheden (Batavia: Commisie voor Volkslectuur, 1921).

${ }^{12}$ Departement van Binnenlandsch-Bestuur.

${ }^{13}$ Departement van Binnenlandsch-Bestuur.
} 
system of license. It is ship administration that became an attention in Batavia within Scheepvaart Aangelegenheden.

In common, the bustle port of Batavia was managing the ship license by signing out the size of the ship. By doing this, Nederlandsch Indie, in the beginning of twentieth centuries, had organized the ships in the harbor well. From the law, the Dutch was resolving the license by size and capacities of the sailed ships. Harbormaster released the license for sailing the sea after the ships had measured by Scheepmeter. ${ }^{14}$ This two methods of license were shaping the harbor to be controlled and managed properly in Nederlandsch Indie.

\section{B. Tax Withdrawal}

Far deep to the corpus of maritime system, one and the most important point that should be explained was tax withdrawal. Although tax was being 'scary phantom' haunting the societies, but the role of tax was important to built and develop the harbor itself. For that, the tax was necessary even an obligation for the certain societies. Within this harbor, entire ships are measured by scheepmeter and paid their tax. For Nederlandsch Indie, the feature point which concerned in scheepvaart aangelegenheden was and how the mechanism of taxes withdrawal.

The first highlight point within tax withdrawal system in Nederlandsch Indie within twentieth century in this regulation was collecting the tax annually by the ship licensing. It means that taxes withdrawal obligated together with the renewal of annual ship license. It means the tax in Nederlandsch Indie include the permission of ship voyages. For the tax amount, it depended on how big the ships were.

Took Aceh as a comparison to make this fact much more clear. Aceh in the eighteenth centuries, obligated all of the new arrival of the harbor to give a number of tribute to the king. ${ }^{15}$ These form implicitly was the tax. Those taxes helped the kingdom to gradually grow into the unimaginable strong empire, remembering that Atjeh in the time was favorable place for trading. For that, the amount of gift that tribute to the king was depending on the racial division such as the ship licenship before. Each ethnic that visited

\footnotetext{
14 Dienst van Scheepvaart, Overzicht Der Reedegrenzen En van de Standplaatsen van Havenmeesters, 1919.

${ }^{15}$ Ingrid Saroda Mitrasing, The Age of Aceh and The Evolution of Kingship 1599-1641 (Leiden: Leiden University, 2011).
} 
harbor of Atjeh will give different number of tax, something that reflected the racial classification. ${ }^{16}$

The other way around, Nederlandsch Indie control the taxes administration along with the Ship License management and organized it in one place, something that also different with any other local kingdoms. ${ }^{17}$ It means that, Within twentieth centuries rather than organize these tax separately, Dutch Reign control the management of license and taxes together with the annual reforms of license sheet. ${ }^{18}$

For managing administration, Dutch organized them along with the annual letter of license release for the ship renewal. So people with their ship should pay a visit to the office of Syahbandar and took care of their license annually together with the number of tax, according to their ship size. ${ }^{19}$ This is way more effective and simple then what local kingdoms did with king as a dominant manager, but this method gave much more opportunities to corrupt the tax because there is no regulation to watched over the process.

\section{Conclusion}

In short, Dutch maritime law in Batavia was influenced by context. It means that this contemporary law which mostly concerning ships and tax might be generated because of the fact that new ports had been established. Regarding to the law, a number of articles were imitation, something that we can find in local kingdoms and reformulate them to be much more relevance. There were three important points which mostly considered within the manuscript. They were harbor manager, ship license and tax withdrawal. Each of these three point had been well-organized by Dutch government. However, no matter ideal the law was, there still some weaknesses. In this particular regulation, the money flow from tax was uncontrolled by any articles, something that gives possibilities to easily corrupt it.

\section{References}

Baihaqi, Ahmad Fauzan, and Zakiya Darojat. "The Transition of the Central Port of Colonial Era : From Old Batavia to TanjungPriok Port.” Journal

\footnotetext{
${ }^{16} \mathrm{KITLV}$, Adat Aceh.

${ }^{17}$ Departement van Binnenlandsch-Bestuur, Scheepvaart Aangelegenheden.

${ }^{18}$ Mr. F.C Heikmeijer, Scheepvaart Verodeningen. Wetten En Verordeningen van Ned-Ind, 1915.

${ }^{19}$ Mr. F.C Heikmeijer.
} 
of Islam and Humanities," 2018.

Blink, H. General View of the Netherlands. Batavia, 1915.

Blusse, Leonard. Visible Cities: Canton, Nagasaki and Batavia and the Coming of Americans. London: Harvard University Press, 2008.

Departement van Binnenlandsch-Bestuur. Scheepvaart Aangelegenheden. Batavia: Commisie voor Volkslectuur, 1921.

Gultom, Annisa. "Kalapa-Jacatra-Batavia-Jakarta: An Old City That Never Gets Old." Journal of Archeology and Fine Arts in Southeast Asia 2, 2018.

Jaelami, Ahmad Halimi. "Undang-Undang Laut Melayu : Undang-Undang Perahu Dan Undang-Undang Berlayar." Pusat Pengkajian Umum Dan Naskah Adat Aceh, 1985.

Kehoe, Marsely L. "Dutch Batavia: Exposing the Hierarchy of the Dutch Colonial City." Journal of Historians of Netherlandish Art 7 (1), 2015.

KITLV. Adat Aceh. Jakarta: Departemen Pendidikan dan Kebudayaan, 1985.

Lapian, Adrian B. Pelayaran Dan Perniagaan Nusantara Abad Ke 16 Dan

17. Jakarta: Komunitas Bambu, 2008.

Lombard, Denys. Kerajaan Aceh. Jakarta: Gramedia, 2014.

Mitrasing, Ingrid Saroda. The Age of Aceh and The Evolution of Kingship 1599-1641. Leiden: Leiden University, 2011.

Mr. F.C Heikmeijer. Scheepvaart Verodeningen. Wetten En Verordeningen van Ned-Ind, 1915.

Mulya, Lillyana. "KEBIJAKAN MARITIM DI HINDIA BELANDA: Langkah Komersil Pemerintah Kolonial." MOZAIK: Jurnal Ilmu-Ilmu Sosial Dan Humaniora 7 (1), 2018.

Scheepvaart, Dienst van. Overzicht Der Reedegrenzen En van de Standplaatsen van Havenmeesters, 1919. 
Overview History Of Nederlandsch-Indie | Rendy Kurniawan

$26 \mid \mathrm{H}$ is t o ria $\mathrm{M}$ a d a $\mathrm{n}$ i a $\mathrm{V}$ ol um e $3(1) 2019$ 